NAMES, Vol. 67 No. 4, December 2019, 245-248

\title{
In Memoriam: John Thomas Algeo (1930-2019)
}

\author{
I.M. NICK
}

\section{Germanic Society for Forensic Linguistics (GSFL)}

Within English linguistics, there are certain academics whose body of work is so substantial, so significant, so fundamental to our current understanding of what the English language is and how it came to be that their surnames take on a kind of luminous aura. What Dylan, Prince, Elvis, and Mozart, Armstrong, Sinatra, Beethoven, and Lennon were to music, so were Trudgill, Svartvik, Quirk, Pyles, Leech, Greenbaum, Crystal, and Algeo to English linguistics. As university students, it was somehow beyond imagination that behind these surnames were real people, with real goals and dreams, challenges and defeats, lives and deaths. As university faculty, the scholarly legacy of these academics was as inspirational as it was awe-inspiring.

I myself first came across Algeo's work in my introductory classes in English linguistics. Required readings like The Origins and Development of the English Language (ISBN-IO: OI $5507055 \mathrm{X}$ ) not only introduced me - as well as countless others around the world - to the maddening yet magnificent processes that led to the formation of the English language today. They also gave delightfully tantalizing clues to the wondrous number of geographical, temporal, and social permutations it might take tomorrow.

A few years later, as a graduate student in search of a dissertation topic, I stumbled across the book On Defining the Proper Name. I still remember how excited I was to learn that there was an entire branch of linguistics devoted to the study of names and naming. I had found my research topic. I wanted to study this history of official names used by the US Census for US American residents of African descent. That initial enthusiasm did not last long. My doctoral supervisor told me that onomastics was neither a serious nor a legitimate pursuit for a linguist. I still remember my profound feelings of frustration and confusion. How could it be that names, a linguistic phenomenon so seminal to every form of communication, had been resolutely relegated to the periphery of linguistic research? It was shortly thereafter that I made another discovery that steeled my resolve to stick to my original idea for my doctoral dissertation.

The article that had such a profound affect upon me was published in a journal called NAMES. The article was "Is a Theory of Names Possible?" by John Algeo - the very same John Algeo whose textbooks were at the very center of 
the English linguistic canon. In that inspirational essay, Algeo likened the people who study names to people who collect stamps.

Some collectors gather their specimens randomly, as they happen to find them, and keep then in an old show box to bring out appropriate occasions for the interest and amusement of friends. Others set about to gather methodically all the specimens of a given kind from a given place, to study [...] names in as minute detail as possible,

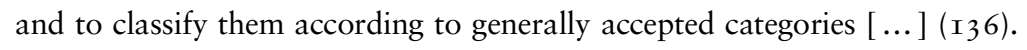

Algeo's amusing analogy was an outstanding description of a revolutionary change that had been taking place in onomastics. Gone were the days that onomastics constituted little more than the eclectic compilations of names. Instead, onomastics was slowly but surely being re-defined by systematic research conducted by experts in linguistic theory and the scientific method. As Algeo described, this seismic shift was a part of an overarching development in linguistics wherein increasingly strenuous efforts were being made to more firmly align the discipline with the so-called "hard sciences." The ultimate aim was to produce more empirically based and theory-driven research. This development was helped in no small measure by the insightful scholarship of John Algeo.

That very fact that a such a highly respected linguist regularly conducted names research did much to help establish onomastics as not only a legitimate but a seminal part of linguistics. Precisely this contribution was stressed by Professor Edward Callary, Professor Emeritus of English at Northern Illinois University. In an e-correspondence with the author, November 3, 20I9, the former NAMES Editor-in-Chief explained that:

John was a great ambassador for name study who did a great deal for establishing onomastics as a legitimate subfield of linguistics. Especially valuable are his early monograph, On Defining the Proper Name, and such articles as "Onomastics as an Interdisciplinary Study" and "Is a Theory of Names Possible?" This seminal article [...] should be read annually by all serious onomasts [... John was a good friend, personal and professional, onomastics will miss him.

As Professor Callary described above, many of Professor Algeo's articles are now roundly considered to be classics with insights that seem to only increase in significance as time goes on. To help introduce this body of work to the next generation of up-and-coming onomastic scholars, former NAMES Editor-in-Chief, Professor Frank Nuessel, re-issued some of Algeo's most influential publications. However, as Professor Nuessel was quick to remind, Professor Algeo's contributions to onomastics were not only to be found in his scientific writings. "I corresponded with John Algeo since the mid-I970s," Professor Nuessel related, "and I had the opportunity to meet him at various professional conferences over the years. He epitomized the phrase 'a gentleman and scholar' in every aspect of his life. He was a very kind and gentle person whose scholarly achievements are prodigious." I

Evidence of Professor Algeo's scholarship is abundant. Alongside his many articles in NAMES, his publications also include: Volume 6 of The Cambridge 
History of the English Language: American English (ISBN-IO: 0521264774); British or American English: A Handbook of Word and Grammar Patterns (ISBNIO: 052I37I376); Fifty Years among the New Words: A Dictionary of Neologisms I94I-I99I (ISBN 978052I4I3770); Problems for Algeo/Buther's Origins and Development of the English Language (ISBN-IO: II33957544); The Power of Thought (ISBN-IO: 8I3I90I564); Reincarnation Explored (ISBN-IO: 0835606244); Unlocking the Door: Studies in the Key to Theosophy (ISBN-Io: 9780835608 I II). In total, he (co)authored or edited nearly thirty books over his lifetime. The diversity of Professor Algeo's large store of publications is a direct reflection of the breadth of his education. After earning a Bachelor of Education from the University of Florida (I955), he went on to earn an MA and a PhD from the University of Florida in I959 and I96I respectively. By I966, his scholarship and service to the university led to his appointment as Assistant Dean of the Graduate School in I969. A year later, after receiving his full professorship, he left the University of Florida and accepted a position in the English Department of the University of Georgia. Four years later he was named Chair of the English Department. Professor Algeo was named a Fulbright Research Fellow and a Guggenheim Fellow at the University of London and served as a Visiting Professor at the University of Erlangen-Nuremberg, in Germany. From 2002-2008, he also served as the International Vice-President of the Theosophical Society. In addition to his many faculty duties, he also managed to serve as the editor of American Speech for an impressive thirteen years, between 1969-82. About this period of editorship, Professor Ronald Butters, longtime ANS member and Professor Emeritus of English and Cultural Anthropology at Duke University, had this to say:

John pretty much saved [the journal] AMERICAN SPEECH from extinction, persuading the American Dialect Society to take over sponsorship (with the enthusiastic support of Alan Metcalf), finding a reliable publisher at the U of Alabama Press, and twisting arms from younger scholars for submissions so as to get the backup issues out in a timely matter (it was way behind schedule when he took over editorship). He was a gentleman as well as a scholar-with a keen sense of humor. ${ }^{2}$

Incredibly, alongside his editorship, he also served as President for the Dictionary of North American English, American Dialect Society, and of course, our own American Name Society. Over the years, Professor Algeo gradually slowed down the pace of his publications, but he never compromised on intellectual quality. For many, many years after his official retirement from the University of Georgia, he continued to research and write. One of his last publications for NAMES was an engaging 200I study in literary onomastics entitled: "A Fancy for the Fantastic: Reflections on Names in Fantasy Literature." At the end of the day, though, in my opinion, one of his most memorable publications appeared many years earlier and was only a few pages long. The piece was a memoriam he had written after the passing of his close colleague, Professor Thomas Pyles (I905-I980). Now, nearly four decades later, I can honestly find no better words to describe Professor Algeo than the words he himself used to honor his dear friend: 
It is easy to picture [him] in that heaven world whither all good onomatologists go. $\mathrm{He}$ is doubtless there observing the naming of angels and contemplating what an essay he might write on that subject (292).

Professor John Thomas Algeo died on the $13^{\text {th }}$ of October 2019 in Bowling Green, Kentucky at the age of 88 -nine years after the death of his beloved wife, Adele. The Algeos are survived by their son Thomas, their daughter Katie, and their five grandchildren.

\section{Notes}

I. Taken from e-correspondence between Professor F. Nuessel and the author on October 3I, 2019.

2. Taken from e-correspondence between Professor R. Butters and the author on October 3I, 2019.

\section{Bibliography}

Algeo, John. 1973. On Defining the Proper Name. Gainesville, Florida: University of Florida Press.

Algeo, John. I980. "In Memoriam: Thomas Pyle (I905-I980)." Names 20, no. 4: 291-292.

Algeo, John. 1985. "Is a Theory of Names Possible?" Names 30, no. 3: I36-I 44.

Algeo, John. I995. Reincarnation Explored. Wheaton, Illinois: Quest Books.

Algeo, John, and Katie Algeo. 2000. "Onomastics as an Interdisciplinary Study." Names 48, no. 3-4: $265-274$.

Algeo, John. 200I. "A Fancy for the Fantastic: Reflections on Names in Fantasy Literature." Names 49, no. 4: $248-253$.

Algeo, John. 200I. Unlocking the Door: Studies in the Key to Theosophy. Wheaton, Illinois: Quest Books. Algeo, John. 2005. The Origins and Development of the English Language. Boston: Wadsworth.

Algeo, John. 2006. British or American English: A Handbook of Word and Grammar Patterns. Cambridge: Cambridge University Press.

Algeo, John, ed. 200I. The Cambridge History of the English Language. Volume 6: American English. Cambridge: Cambridge University Press.

Algeo, John and Adele Algeo. I991. Fifty Years among the New Words: A Dictionary of Neologisms I94 II99I. Cambridge: Cambridge University Press.

Algeo, John, Carmen Acevedo. Butcher, and Thomas Pyles. 2014. Problems for Algeo/Butcher's Origin and Development of the English Language: A Workbook. Boston: Woodsworth Learning.

Algeo, John, and Shirley J. Nicholson. 2008. The Power of Thought. Wheaton, Illinois: Quest Books.

\section{Notes on contributor}

I. M. Nick holds a BA (Germanics), BSc (Clinical/Abnormal Psychology), MA (German Linguistics), MSc (Forensic and Investigative Psychology), PhD and the German "Habilitation” (English Linguistics). Her research includes forensic linguistics, multilingualism, language-policy, Holocaust studies, and onomastics. She is the President of the Germanic Society for Forensic Linguistics (GSFL), the immediate Past President of the American Name Society (ANS), and the current Editor-in-Chief of NAMES.

Correspondence to: I. M. Nick Germanic Society for Forensic Linguistics (GSFL). Email: mavi.yaz@web.de 